\title{
COMUNIC̣AÇÃO
}

\section{O ENSINO DOS ACIDENTES POR ANIMAIS PEÇONHENTOS NAS ESCOLAS MÉDICAS BRASILEIRAS}

\author{
Benedito Barraviera
}

Os acidentes por animais peçonhentos constituem problema de Saúde Pública sobretudo nos países das regiões tropicais e subtropicais do mundo, quer pela quantidade, quer pela gravidade de muitos deles. No Brasil, de janeiro a julho de 1990 o Ministério da Saúde divulgou a notificação de 9.396 casos de acidentes ofídicos ${ }^{8}, 44$ dos quais com evolução fatal e $13 \mathrm{com}$ sequelas permanentes. A maioria destes acidentes foi causada por serpentes do gênero Bothrops (74,80\%), seguido das serpentes do gênero Crotalus $(7,20 \%)$.

No mesmo período, foram notificados 1.347 acidentes escorpiônicos ${ }^{7}$ com 4 óbitos. Entre os escorpiões que foram trazidos pelos doentes e identificados nos serviços que os atenderam, destacam-se o Tityus bahiensis e o Tityus serrulatus.

Os acidentes araneídicos ${ }^{6}$ ocorridos no mesmo período foram 1.532 casos, com um óbito. A maioria dos acidentes foi causada por aranhas dos gêneros Phoneutria $(38,3 \%)$ eLoxosceles $(26,1 \%)$. Os acidentes causados por abelhas e vespas não são notificados, daí não haver dados disponíveis para serem analisados, embora tenham sido relatados casos fatais ${ }^{5}$.

Por outro lado, a localização do tema "Acidentes por animais peçonhentos" no currículo médico não é bem definida. Assim é que algumas Escolas o incluem na Disciplina de Moléstias Infecciosas e Parasitárias, ou na de Doenças Tropicais e Infecciosas, pela natureza de seu corpo de doutrina.

Tendo em vista a relevância do tema e a necessidade de considerá-lo na formação de todos os médicos brasileiros, pareceu-nos pertinente a tentativa de avaliação do estado atual do ensino dos "Acidentes por animais peçonhentos" no Brasil, por intermédio da análise de questionário denominado "Projeto Peçonha", que foi enviado em 1989 para todas as 75 Escolas Médicas do País.

\footnotetext{
Departamento de Doenças Tropicaise Diagnóstico por Imagem da Faculdade de Medicina de Botucatu e Centro de Estudos de Venenos e Animais Peçonhentos da UNESP, Botucatu, SP. Endereço para correspondência: Dr. Benedito Barraviera, Caixa Postal 576, 18618-000 Botucatu, SP.

Recebido para publicação em 10/05/91.
}

Os resultados da presente pesquisa revelam que a maioria dos alunos de graduação recebe aulasteóricas sobre o assunto, embora, apenas $58 \%$ dos estudantes estagiem em Instituições credenciadas, sendo a maioria delas constituídas de Hospitais Escolas e Centros de Saúde. O treinamento insuficiente na graduação, repete-se na residência médica, onde apenas $56 \%$ dos médicos residentes recebem treinamento. A maioria dos residentes são de Clínica Médica, seguida de Doenças Infecciosas e Parasitárias.

Deve ser salientado que os acidentes por animais peçonhentos constituem-se num dos importantes temas das Doenças Tropicais e deveriam obrigatoriamente fazer parte do corpo de doutrina desta especialidade médica.

Este assunto foi abordado pela primeira vez no Congresso da Sociedade Brasileira de Medicina Tropical em 19821 sob a rubrica de "Miscelânea". Naquela oportunidade foram apresentados 6 trabalhos, perfazendo $2,19 \%$ do total dos trabalhos apresentados. Em $1985^{2}$, no Congresso realizado em São Paulo, o assunto recebeu pela primeira vez a designação de "Animais Peçonhentos" e foram apresentados 13 trabalhos perfazendo $6,07 \%$ do total. Em $1988^{3}$, por ocasião do $24^{\circ}$. Congresso realizado em Manaus, foi ministrado o $1^{\text {o. Curso }}$ sobre "Acidentes por animais peçonhentos". Em $1990^{4}$, durante $026^{\circ}$. Congresso, foram apresentados 27 trabalhos, perfazendo $7,29 \%$ do total dos trabalhos apresentados.

Como pode-se perceber, os acidentes por animais peçonhentos estão gradativamente sendo atendidos pelos médicos tropicalistas, pois como mostrou esta pesquisa, $49 \%$ das Disciplinas de Doenças Infecciosas e Parasitárias são responsáveis pelo ensino e treinamento dos alunos de graduação e residentes. Apesar desta cifra ser bastante tímida, o assunto já está em parte integrado ao corpo de doutrina das Doenças Tropicais e Infecciosas. Isto porque do ponto de vista epidemiológico os animais peçonhentos das regiões tropicais apresentam peculiaridades regionais próprias e inerentes a cada continente.

A etiopatogenia destes acidentes também possui 
Comunicação. Barraviera B. O ensino dos acidentes por animais peçonhentos nas Escolas Médicas Brasileiras. Revista da Sociedade Brasileira de Medicina Tropical 25:203-204, jul-set, 1992.

semelhanças com algumas doenças infecciosas que causam intoxicação, tais como difteria, tétano e botulismo. A diferença destas últimas em relação às primeiras, é o fato de que os animais peçonhentos inoculam grande quantidade de toxinas de uma só vez, ao passo que os agentes bacterianos vão liberando lentamente suas toxinas no hospedeiro. É possível que o sistema imune comporte-se de maneira diferente para as duas situações, muito embora o produto final seja uma intoxicação mais ou menos grave dependendo da situação.

Dessa maneira, os médicos que atuam na área das Doenças Tropicais e Infecciosas devem encarar esta Disciplina do ponto de vista de "Problema de Saúde Pública" das regiões tropicais sob três aspectos: as doenças infecciosas e parasitárias propriamente ditas, os acidentes por animais peçonhentos e a desnutrição. Os médicos tropicalistas devem aceitar com mais convicção os acidentes por animais peçonhentos e incluir definitivamente este assunto no corpo de doutrina das Doenças Tropicais, uma vez que as grandes entidades formadoras de profissionais nesta área são os Hospitais Escolas e as Disciplinas de Doenças Infecciosas e Parasitárias como comprovou esta pesquisa.

Coerente com este pensamento, a Faculdade de Medicina de Botucatu da UNESP, é uma das que mantém o ensino e a assistência aos doentes picados por animais peçonhentos, dentro do corpo de doutrina das Doenças Infecciosas e Parasitárias. Assim é que os alunos de graduação recebem aulas teóricas no $4^{o}$ ano e atendem aos doentes durante o $5^{\circ}$ ano por ocasião do internato. Os médicos residentes de Doenças Infecciosas e Parasitárias, Clínica Médica, Dermatologia e Neurologia, quando estagiam na enfermaria de Moléstias Infecciosas e Parasitárias, recebem aulas teóricas e treinamento, além de participarem das pesquisas desenvolvidas pelos docentes.

Por outro lado, apenas $27 \%$ das Disciplinas cuidam dos acidentes produzidos por animais peçonhentos mantêm linhas de pesquisa na área: Um dos fatores limitantes é a falta de venenos preparados especificamente para pesquisa. Deveríamos ter à disposição dos pesquisadores venenos cristalizados e/ou liofilizados da melhor procedência a fim de que este vasto campo pudesse serampliado e aprimorado. Neste sentido, a UNESP diagnosticou esta necessidade e criou recentemente o Centro de Estudos de Venenos e Animais Peçonhentos (CEVAP), que terá por objetivos básicos a produção de veneno para fornecimento aos pesquisadores, estimular a pesquisa básica e tecnológica na área dos venenos, além de propiciar a formação de pesquisadores.

Por fim, deve ser salientado que as Escolas Médicas Brasileiras necessitam reavaliar o ensino dos acidentes por animais peçonhentos, incluindo definitivamente este tema como matéria regular do curriculum das Disciplinas relacionadas à Medicina Tropical. Isto contribuiria sobremaneira para estimular os médicos recém-formados a pesquisarem o assunto, refletindo-se no final em uma melhor assistência médica à nossa população.

\section{REFERÊNCIAS BIBLIOGRÁFICAS}

1. Acidentes por animais peçonhentos. In: Resumos do XXIV Congresso da Sociedade Brasileira de Medicina Tropical, Manaus p.114-123, 1988.

2. Acidentes por animais peçonhentos. In: Resumos do XXVI Congresso da Sociedade Brasileira de Medicina Tropical, Natal p.87-107, 1990.

3. Anais do XVII Congresso da Sociedade Brasileira de Medicina Tropical, Ribeirão Preto p.J1-J16, 1982.

4. Animais peçonhentos. In: Resumos do XXI Congresso da Sociedade Brasileira de Medicina Tropical, São Paulo p.21-28, 1985.

5. Mendes RP, Meira DA, Teixeira UA, Molinari H, Rodrigues PS, Coelho KYR. Acidente por múltiplas picadas de abelha: relato de dois casos. Revisão da literatura e discussão da patogenia e tratamento. Arquivos Brasileiros de Medicina 64:81-88, 1990.

6. Ministério da Saúde. Acidentes araneídicos. Contribuição ao estudo da morbidade. Secretaria Nacional de Ações Básicas de Saúde. Ano V, n 29 / 30, 1990.

7. Ministério da Saúde. Acidentes escorpiônicos. Contribuição ao estudo da morbidade. Secretaria Nacional de Ações Básicas de Saúde. Ano V, $n^{0} 29$ / 30, 1990.

8. Ministério da Saúde. Acidentes ofídicos. Contribuição ao estudo da morbidade. Secretaria Nacional de Ações Básicas de Saúde. Ano V, nº 47 । 48, 1990. 